\title{
Aplikasi Digital Payment Pada Transaksi Di Ar-Raihan Banyuwangi
}

\author{
Novan Jefriandi ${ }^{1}$, M. Taufiq $^{1{ }^{*}}$ \\ ${ }^{1}$ Manajemen Informatika; STIKOM PGRI Banyuwangi; JIn. A. Yani 80 banyuwangi, Jawa \\ Timur, Indonesia e-mail: novanstikom@gmail.com, mtaufiq39@gmail.com \\ ${ }^{*}$ Korespondensi: e-mail: mtaufiq39@gmail.com
}

Diterima: 20 Nopember 2020; Review: 04 Desember 2020; Disetujui: 18 Desember 2020

Cara sitasi: Jefriandi N, Taufiq M. Aplikasi Digital Payment pada Transaksi di Ar-Rahman Banyuwangi. Bina Insani ICT Journal. Vol. 7 (2): 166-176.

\begin{abstract}
Abstrak: Payment gateway menjadi sangat populer dikala pandemi seperti saat ini. Dengan payment gateway kita dapat melakukan pembayaran kemana saja tanpa harus menggunakan uang fisik. Hal ini didukung oleh kebijakan pemerintah untuk mengurangi pertemuan fisik dengan orang lain. Ar-raihan banyuwangi adalah salah satu outlet yang menyediakan jasa retail dan cafe yang menawarkan banyak barang, sehingga banyak transaksi yang dilakukan tiap harinya. Dengan keadaan seperti itu maka untuk mendukung kebijakan pemerintah dibutuhkan suatu metode pembayaran yang tidak mengharuskan bertemunya bertemunya pedagang dalam hal ini pegawai outlet dengan para konsumen. Dengan demikian pembayaran yang harus dilakukan dapat dicek sendiri oleh konsumen. Begitupun dengan vendor penerima pembayaran yang dimiliki oleh fitur pembayaran. Sehingga memudahkan dalam hal pembayaran dan laporan transaksi.
\end{abstract}

Kata kunci: ar-raihan, outlet, payment gateway.

Abstract: Payment gateways are becoming very popular during a pandemic like today. With a payment gateway, we can make payments anywhere without having to use physical money. This was supported by government policies to reduce physical encounters with other people. ArRaihan Banyuwangi is one of the outlets that provide retail and cafe services that offer a lot of goods so that many transactions are carried out every day. With such circumstances, to support government policy a payment method is needed that does not require the meeting of traders, in this case, outlet employees with consumers. Thus the payments that must be made can be checked by consumers themselves. Likewise with the payment receiving vendor that is owned by the payment feature. Making it easier in terms of payments and transaction reports.

Keywords: ar-raihan, outlet, payment gateway.

\section{Pendahuluan}

Sejak pandemi virus corona merebak diseluruh dunia, who sebagai garda terdepan dalam kesehatan dunia memberikan arahan agar mengurangi interaksi dengan orang lain sehingga transaksi jual beli pun menjadi terhambat. Pemerintah Indonesia pun tidak ketinggalan untuk memberikan arahan yang sama, bahkan jam kerja pada toko, supermarket dan banyak tempat yang dapat menimbulkan kerumunan dibatasi jam operasionalnya [1] [2] [3].

Bukan hanya itu saja untuk transaksi keuangan diharapkan menggunakan transaksi non tunai. Sehingga banyak outlet yang membangun metode pembayaran non tunai. Transaksi non tunai menggunakan jasa payment gateway yang banyak berkembang saat ini. Penggunaan payment gateway pada pembayaran outlet menjadi salah satu solusi pembayaran yang bisa digunakan dalam keadaan saat ini [4]. Namun untuk penelitian ini akan dibangun sebuah payment gateway sederhana yang dikelola sendiri oleh pihak outlet. 
Ar-Raihan memiliki outlet yang ada di Banyuwangi kota didirikan 2 lantai dimana lantai pertama digunakan sebagai outlet minimarket sedangkan lantai 2 digunakan untuk rumah makan. Karena lokasinya yang cukup strategis di jantung kota menyebabkan transaksi yang dilaksanakan sehari-hari sangat banyak sehingga dibutuhkan sistem yang dapat membantu menangani transaksi yang terjadi.

Dengan sistem yang terintegrasi dengan payment gateway transaksi yang terjadi akan lebih cepat [5]. Bukan hanya itu dengan integrasi payment gateway [6], maka outlet Ar-Raihan mematuhi peraturan yang dianjurkan oleh pemerintah.

\section{Metode Penelitian}

Dalam penelitian ini hal pertama yang dilakukan oleh peneliti adalah dengan melakukan pendefinisian kebutuhan yang ada pada objek penelitian dalam hal ini outlet Ar-Raihan Banyuwangi. Dengan mendatangi outlet untuk bertemu dengan pemilik dan karyawan outlet. Dalam proses ini peneliti melakukan wawancara kepada pemilik dan beberapa karyawan yang ada. Setelah data didapatkan maka langkah selanjutnya peneliti melakukan proses analisis.

Dalam proses analisis peneliti menganalisa data yang didapat ketika proses pendefinisian kebutuhan. Dari hasil analisa didapatkan bahwa masalah yang dihadapi oleh outlet dapat diselesaikan dengan sistem yang terintegrasi dengan payment gateway [7].

Setelah hasil analisa selesai kemudian peneliti melakukan penerjemahan sistem yang akan dibuat dalam hal ini dilakukan pendesainan dengan menggunakan UML. Desain UML yang dibuat untuk menggambarkan kerja sistem yang akan dibuat. Serta menggambarkan kebutuhan sistem yang akan dibuat.

Langkah selanjutnya adalah setelah desain dan kebutuhan sistem sudah selesai, maka proses implementasi dapat dilakukan. Sistem yang dibangun menggunakan android studio dengan bahasa pemrograman java [8], untuk backend mengggunakan bahasa pemrograman php, sedangkan database yang digunakan menggunakan MySQL [9] [10].

Sebagai acuan dalam pembuatan sistem diperlukan adanya bisnis proses, dalam bisnis proses yang dibuat melibatkan 3 aktor yaitu calon custumer, admin dan pemilik. Dimana calon kostumer memiliki akses terhadap dashboard dan informasi transaksi yang ia lakukan. Admin dapat melakukan login, input data dan informasi sedangkan pemilik hanya menerima informasi tentang transaksi yang dilakukan pada gambar 1 .

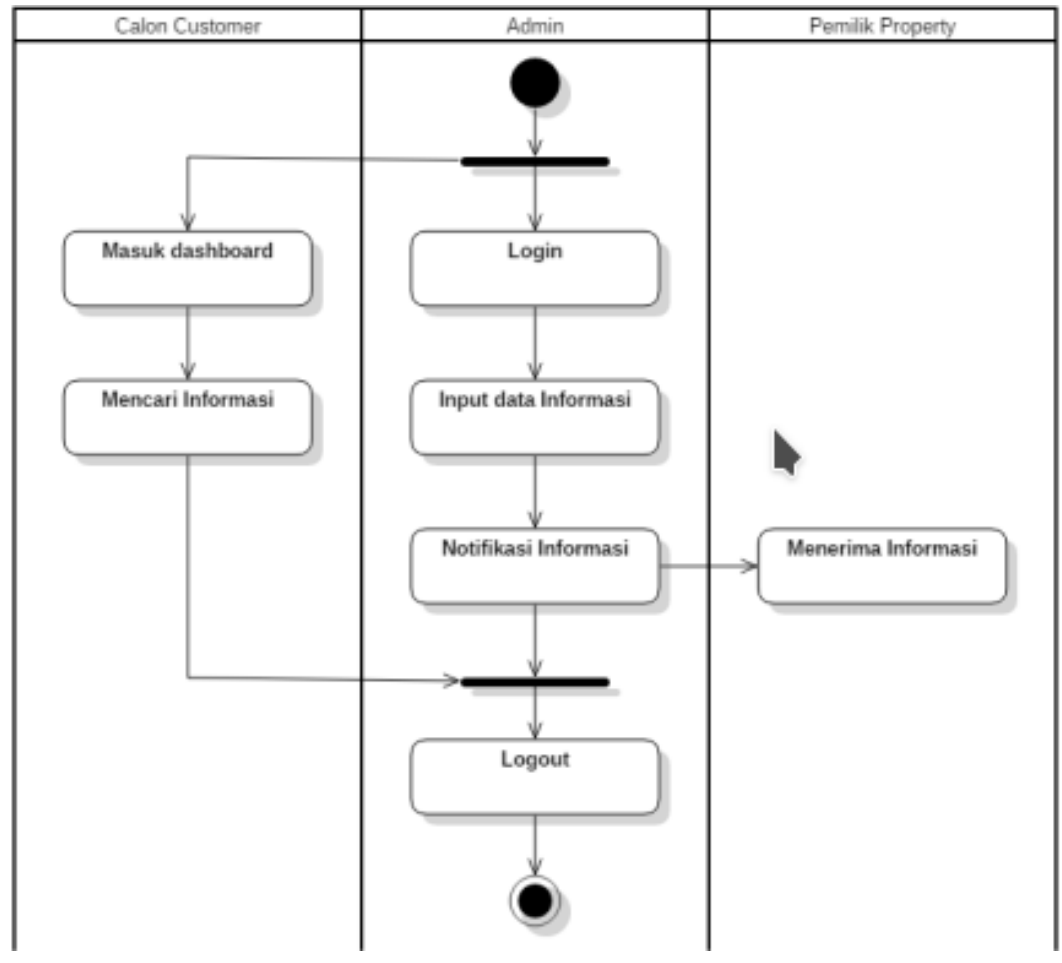

Sumber: Hasil Penelitian (2020)

Gambar 1. Bisnis proses 
Sedangkan transaksi yang digambarkan dalam use case diagram menjelaskan fungsi apa saja yang dapat dilakukan user dalam sistem yang dibuat yaitu user/konsumen melakukan login dan setor(depost) dan kemudian diterima admin dan menginputkan data user untuk dikirim depositya dan laporan pada gambar 2 .

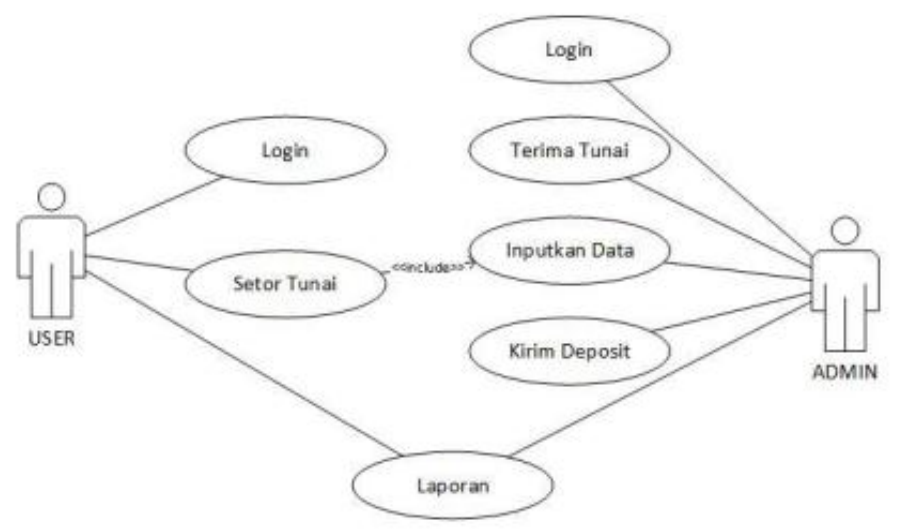

Sumber: Hasil Penelitian (2020)

Gambar 2. Use Case Diagram

Desain form yang digunakan dalam sistem pada tabel 1.

Tabel 1. Rancangan antarmuka

\begin{tabular}{ll}
\hline No Rancangan Antarmuka & \multicolumn{1}{c}{ Deskripsi } \\
\hline 1. & $\begin{array}{l}\text { Tampilan antarmuka login dibuat untuk semua aktor dapat } \\
\text { masuk kedalam sistem yang digunakan. Untuk dapat } \\
\text { masuk kedalam sistem dibutuhkan username dan } \\
\text { password. Jika user belum memiliki akun maka dapat } \\
\text { memilih menu buat akun. }\end{array}$ \\
\hline 3. & $\begin{array}{l}\text { Setelah sukses login konsumen akan diajak masuk ke } \\
\text { dashboard yang isinya nama dan saldo yang dimiliki. }\end{array}$ \\
\hline 4. & $\begin{array}{l}\text { Untuk halaman dashboard admin akan ditampilkan data } \\
\text { peserta dan jumlah saldo yang dimiliki. }\end{array}$ \\
\hline
\end{tabular}

Sumber: Hasil Penelitian (2020) 


\section{Hasil dan Pembahasan}

Pembuatan payment gateway yang digunakan untuk alternatif pembayaran dikala pandemi ini, peneliti menggunakan platform android studio dengan bahasa pemrograman java, sedangkan backendnya menggunakan bahasa pemrograman PHP.

\section{Pembuatan Backend}

Implementasi pembuatan payment gateway dimulai dengan membuat backend terlebih dahulu. Desain database yang digunakan dapat dilihat pada gambar 3.

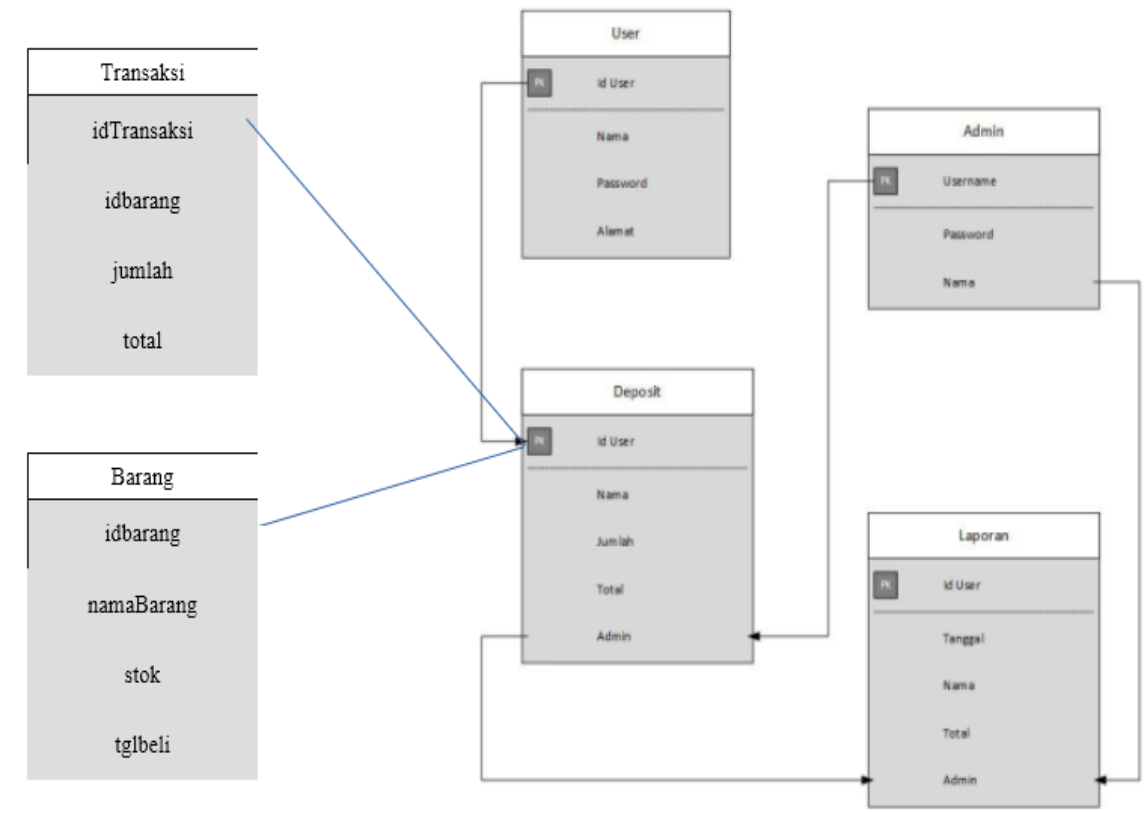

Sumber: Hasil Penelitian (2020)

Gambar 3. Desain database payment gateway

Dari desain database ini kita dapat melihat bahwa yang dapat melakukan deposit dana adalah user yang sudah terdaftar dimana user yang terdaftar nantinya akan mendapatkan akun agar dapat login kesistem.

Proses melakukan deposit masih menggunakan metode setor langsung kepada pegawai dengan baik tunai maupun transfer. Setelah transfer konsumen melakukan konfirmasi ke admin agar dapat ditambahkan kedalam saldo akun yang dimiliki.Tugas admin dalam hal ini sebagai penerima pendaftaran dan deposit saldo serta cetak laporan.

Untuk membuat backend dengan menggunakan php kita memerlukan server lokal yang dapat kita buat dengan xampp yang dapat didownload di website resminya (https://www.apachefriends.org/index.html). Sesuaikan installer yang didownload dengan OS yang digunakan di PC/laptop yang digunakan. Dalam hal ini peneliti menggunakan versi terbaru dengan dukungan PHP 8.0 dan MariaDB 10.4.17. Buatlah sebuah project di htdocs dengan nama topup dan tempatkan semua coding backend disana.

\section{Pembuatan Frontend}

Frontend sistem menggunakan android studio sehingga aplikasi akan dijalankan diperangkat mobile android. Untuk menjalankan aplikasi yang dibuat dapat menggunakan emulator bawaan android studio ataupun emulator dari pihak lain, selain itu kita juga dapat menggunakan perangkat fisik dalam hal ini kita dapat menggunakan handphone yang kita gunakan.

\section{Halaman Login}

Form Login ini adalah form untuk masuk ke halaman dashboard admin atau user. Dashboard yang dituju sesuai dengan level akun yang dimiliki. Jika pengguna memiliki level sebagai user konsumen maka akan dibawa ke halaman dashboard user sedangkan jika 
pengguna memiliki level sebagai admin, maka user akan dibawa ke halaman dashboard admin. Pada halaman ini terdapat dua text filed username, password dan tiga tombol button yang fungsinya untuk menjalankan aplikasi.

Pada awal mengakses sistem kita akan dibawa ke halaman login dimana untuk dapat masuk kita diminta untuk memasukkan username dan password serta menekan tombol login. Namun jika belum memiliki akun kita dapat melakukan registrasi dengan menekan tombol daftar yang disediakan. Sedangkan kalau kita ingin membatalkan proses login kita dapat menekan tombol batal yang ada disamping tombol login pada gambar 4 .

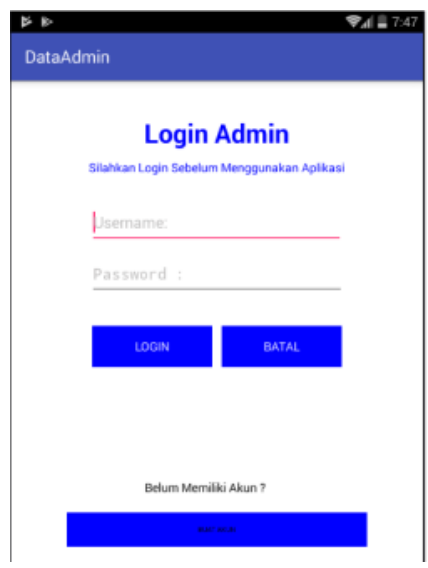

Sumber: Hasil Penelitian (2020)

\section{Gambar 4. Frontend Halaman login admin}

Jika user belum menginputkan apa-apa namun sudah menekan tombol login akan diberikan peringatan untuk memasukkan username dan password terlebih dahulu. Jika user menginputkan username dan password yang salah maka akan ditampilkan peringatan yang berbeda sebagai tanda bahwa yang diinputkan user salah.

Namun jika sudah sukses maka akan ditampilkan peringatan bahwa login sukses dan halaman akan dipindahkan ke halaman dashboard admin atau user.

\section{Halaman Dashboard}

Halaman dashboard dibedakan menjadi 2 yaitu: dashboard user dan admin. Halaman dashboard admin berisi menu topup dan riwayat topup. Dihalaman topup akan ada list user yang dapat diisi saldo depositnya.

Untuk melakukan deposit user dapat menyetorkan dana yang akan dimasukkan kedalam saldo kepada pagawai outlet atau dapat melakukan transfer ke nomor rekening yang disediakan oleh outlet. Setelah itu user melakukan konfirmasi kepada pegawai yang menjadi admin untuk diinputkan dana yang sudah disetorkan.

Setelah menerima konfirmasi pegawai akan melakukan input dana topup kepada akun user yang melakukan setor dana pada gambar 5 .

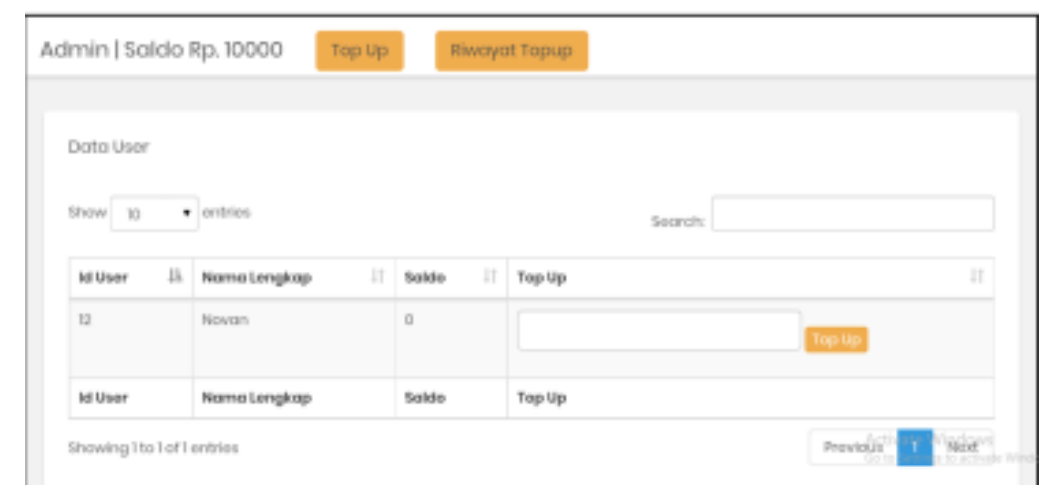

Sumber: Hasil Penelitian (2020)

Gambar 5. Halaman Dashboard admin. 
Sedangkan untuk user setelah melakukan login user akan dibawa ke halaman dashboard user. Dashboard user akan berisi menu yang dapat dipesan di outlet Ar-Raihan, user dapat memesan menu yang ada dengan melakukan klik pada menu yang ada. Kemudian menambahkan jumlah barang yang dipesan pada gambar 7 .

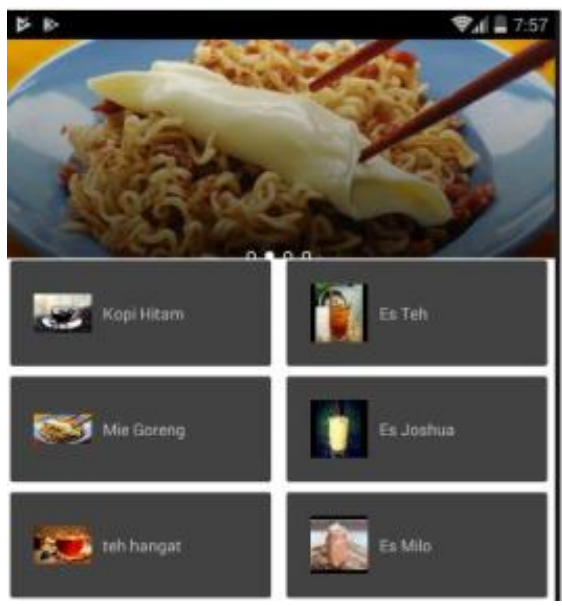

Sumber: Hasil Penelitian (2020)

\section{Gambar 7. Halaman dahsboard user}

Pemanggilan query setiap file yang ada pada folder yang kemudian di tampilkan di halaman user. Setelah user berhasil login maka otomatis halaman ini yang akan di tampilkan. Di halaman ini terdapat sebuah button id menu 1, apabila diklik button tersebut maka akan pindah otomatis form pesanan user (http://192.168.43.190/topup/user/index.php)

\section{Form Pesanan User}

Form Pesanan User ini adalah form untuk masuk ke halaman dashboard pesanan. Pada halaman ini terdapat saldo user dan menu pesanan serta harga pesanan dan button berwarna kuning yaitu button topup dan riwayat pada gambar 8 .

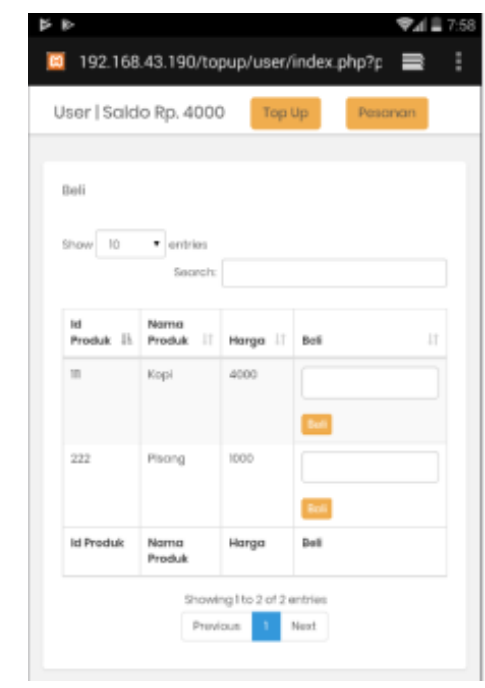

Sumber: Hasil Penelitian (2020)

Gambar 8. Halaman pemesanan user

Setelah admin berhasil login maka otomatis halaman ini yang akan di tampilkan. Di halaman ini terdapat query untuk menambahkan riwayat. Pada topup terdapat tabel admin yang diubah saldo melalui perhitungan pengurangan dengan saldo. Apabila saldo tersebut mempunyai nilai saldo lebih dari 0 maka pembelian akan berhasil jika nilai saldo kurang dari 0 maka pembelian gagal. 


\section{Form Riwayat User}

Form Riwayat User adalah halaman untuk menampilkan hasil hasil transaksi yang telah dibeli oleh user. Pada halaman ini akan ditampilkan riwayat pesanan yang pernah dilakukan oleh user pada gambar 9 .

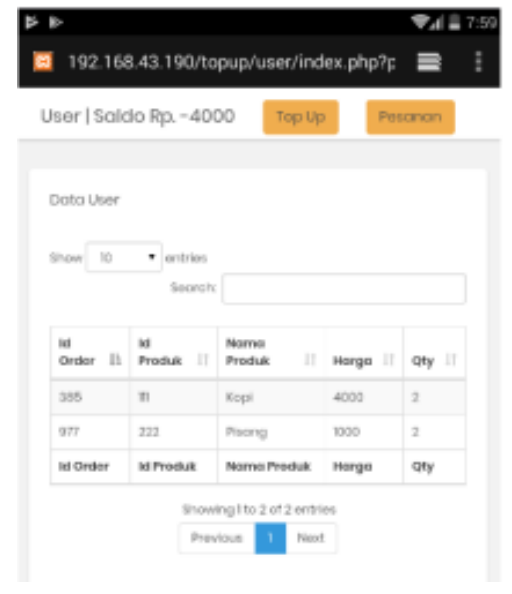

Gambar 9. Halaman riwayat user

\section{Uji Coba}

Seperti yang telah kita ketahui bahwa uji coba merupakan tahap dimana sistem aplikasi siap dioperasikan pada penerapan yang sebenarnya, dari sini kita bisa mengetahui apakah sistem akan benar-benar mendapatkan hasil yang sesuai dengan tujuan yang diinginkan sebelum program ini digunakan. Uji coba penelitian ini terdiri dari halaman admin dan halaman user. Maka pada bab ini peneliti akan melakukan uji coba hasil rancangan tersebut menjadi sebuah program aplikasi.

\section{Uji Coba Halaman Admin}

Tahapan uji coba di bagain backend atau halaman admin akan dilakukan dengan cara pengelolahan data yang nantinya akan di kirimkan ke user.

\section{Admin Login}

Untuk masuk dalam sistem informasi ini maka admin harus terlebih dulu melakukan login. Pada menu login terdapat 2 data yang harus di isi oleh admin agar dapat masuk ke halaman dashboard, data tersebut memasukkan berupa username dan password kemudian tekan button login. Jika berhasil akan masuk ke menu dashboard pada gambar 10 .

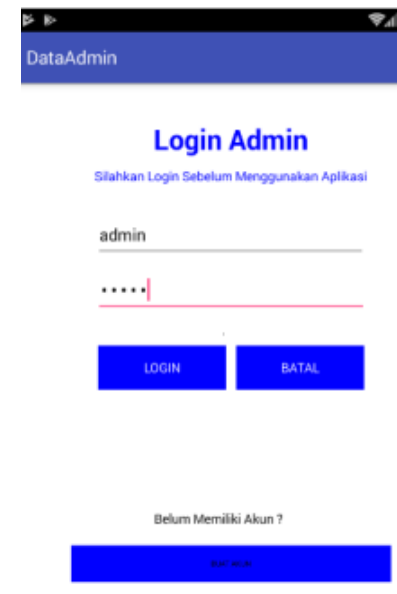

Sumber: Hasil Penelitian (2020)

Gambar 10. Uji coba admin login 
Dihalaman login admin wajib menginputkan data username dan password lalu tekan button login yang berwarna biru untuk melanjutkan ke dashbord admin.

\section{Dashboard Admin}

Pada halaman ini setelah admin berhasil login maka akan ditampilkan beberapa menu button, yaitu: topup dan riwayat topup. Untuk melakukan topup kita harus menginputkan data dan tekan tombol topup yang berwarna kuning untuk melakukan topup pada gambar 11.

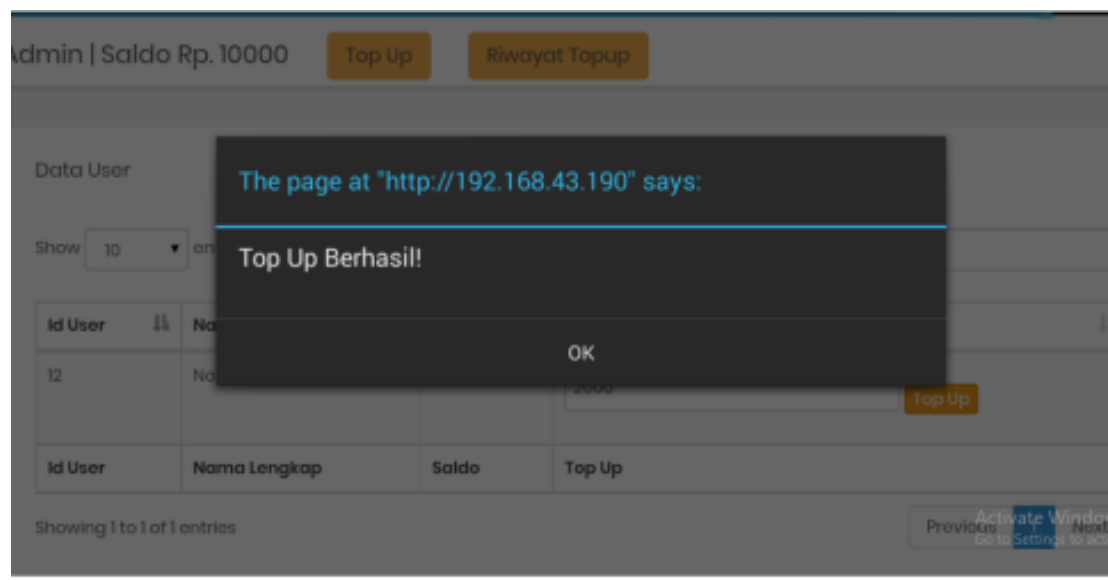

Sumber: Hasil Penelitian (2020)

Gambar 11. Uji coba topup berhasil

Apabila berhasil melakukan topup maka akan keluar sebuah popup yang bertuliskan topup berhasil.

\section{Uji Coba Halaman User}

Tahapan uji coba di halaman user akan dilakukan dengan cara pengelolahan data untuk melakukan login pada gambar 12.

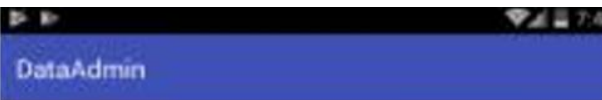

Login Admin

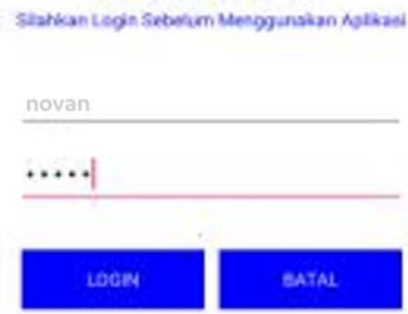

Dedam Mamilei Meun ?

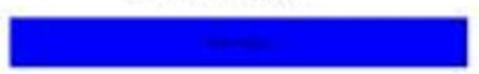

Sumber: Hasil Penelitian (2020)

Gambar 12. Uji coba login user

Ditahap ini pengguna harus menginputkan data user dan pasword dan lalu tekan login apabila sukses kita akan langsung dipindahkan di dashbord user. 


\section{Dashboard User}

Pada halaman ini setelah user berhasil login maka akan ditampilkan beberapa menu yang nantinya dapat dikelolah oleh user. Menu-menu diatas terdapat button menu makanan apabila kita menekan button tersebut, maka user akan dipindahkan dipesanan untuk meanjutkan transaksi pada gambar 13.

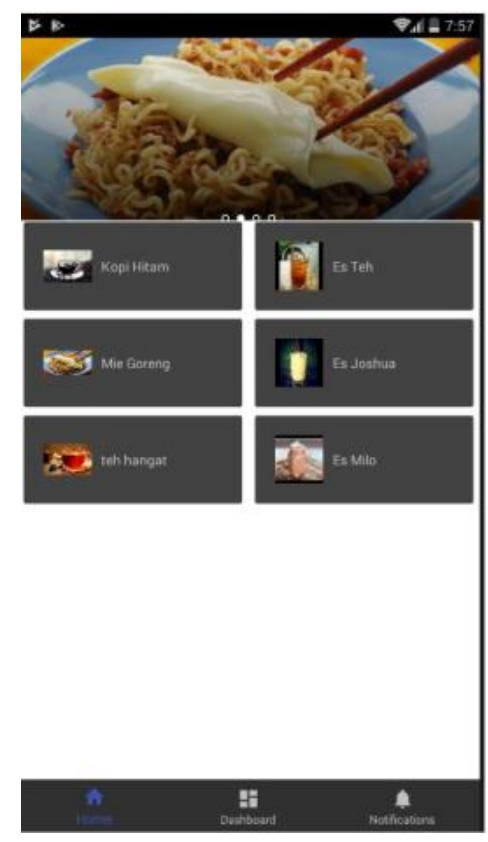

Sumber: Hasil Penelitian (2020)

Gambar 13. Uji coba dasbord user

\section{Uji coba data pesanan user}

Setelah user menekan button menu makanan. Pada halaman data pesanan terdapat button topup dan riwayat. Untuk melanjutkan transaksi user menekan button topup lalu menginputkan data dan menekan button beli yang berwarna kuning untuk melanjutkan transaksi pada gambar 14 .

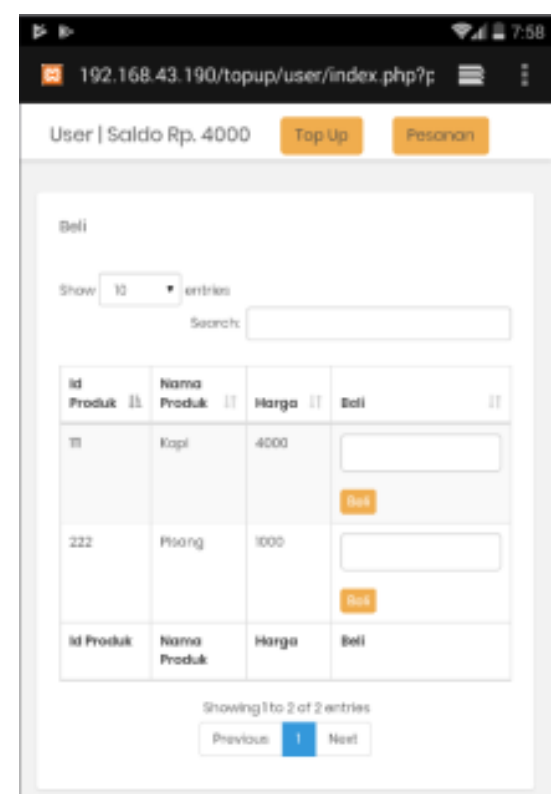

Sumber: Hasil Penelitian (2020)

Gambar 14. Uji coba data pesanan user 
Setelah menekan button beli maka otomatis akan muncul popup topup berhasil yang menandakan proses transaksi telah sukses pada gambar 15.

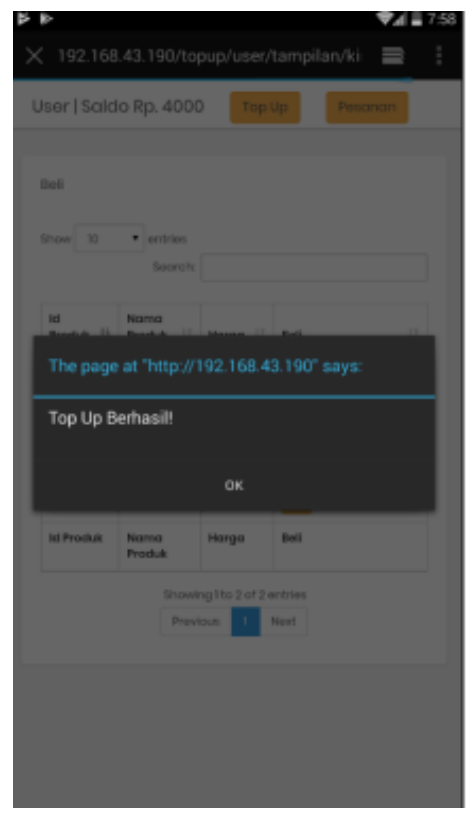

Sumber: Hasil Penelitian (2020)

Gambar 15. Uji coba topup berhasil

\section{Uji Coba Riwayat Pembelian}

Apabila user berhasil melakukan transaksi user dapat melihat riwayat pembelian. Dengan cara menekan button pesanan yang berwarna kuning untuk dialihkan ke riwayat pesanan pada gambar 16 .

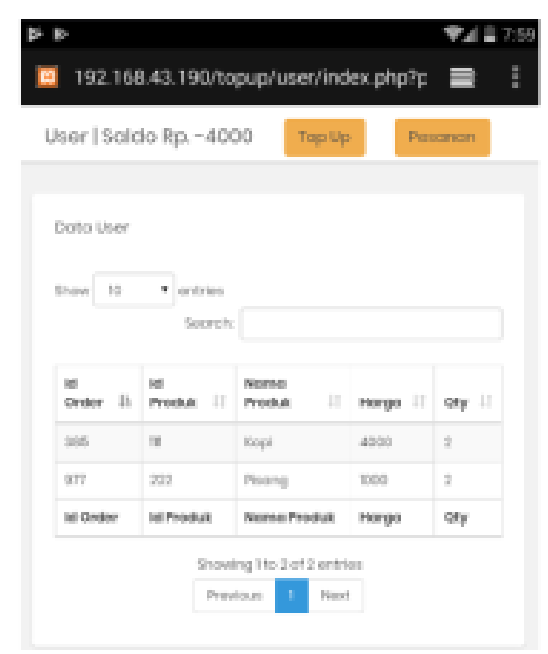

Sumber: Hasil Penelitian (2020)

Gambar 16. Uji riwayat pesanan

\section{Kesimpulan}

Menggunakan payment gateway sendiri memang memudahkan dalam melakukan pembayaran secara cepat namun dengan keterbatasan resource diperlukan adanya kolaborasi dengan pihak lain yang memberikan layanan payment gateway yang sudah dilakukan secara profesional. Meskipun tidak menutup kemungkinan untuk tiap outlet ataupun tempat usaha lain membuat secara mandiri dalam hal pembuatan dan penggunaan payment gateway untuk outlet yang dimiliki. 


\section{Referensi}

[1] M. Najib and F. Fahma, "Investigating the adoption of digital payment system through an extended technology acceptance model: An insight from the Indonesian small and medium enterprises," Int. J. Adv. Sci. Eng. Inf. Technol., vol. 10, no. 4, pp. 1702-1708, 2020.

[2] D. Hariyadi, B. Nakulo, I. D. Sari and F. N. Aini, "Evaluasi Usability Sistem Informasi Payment Gateway Cv Adikara Payment," Indones. J. Bus. Intell., vol. 3, no. 1, pp. 14-19, 2020.

[3] T. H. Makmun, Sistem Informasi Penjualan Batik Khas Banyuwangi. 2020.

[4] A. Riswantio, "Digitalisasi Warung Sembako Dan Terintegrasi Dengan Payment Gateway Berbasis Syariah," vol. 4, no. 2, pp. 196-203, 2020.

[5] D. A. Lestari, E. D. Purnamasari and B. Setiawan, "Pengaruh Payment Gateway terhadap Kinerja Keuangan UMKM," J. Bisnis, Manajemen, dan Ekon., vol. 1, no. 1, pp. 1-10, 2020.

[6] M. Karismariyanti, "Perancangan Sistem Informasi Akuntansi Penjualan dengan Pembayaran Elektronik (e-Payment)," J. Teknol. Inf., vol. 1, no. 7, pp. 238-244, 2014.

[7] R. P. Indahningrum, "Aplikasi M-Commerce Penjualan Spare Part Motor Honda CB Klasik Berbasis Android," Digilib STIMIK Akakom Yogyakarta, vol. 2507, no. 1, pp. 1-9, 2020.

[8] F. A. Hendraswara, Suprihadi and C. Fibriani, "Perancangan Pemesanan Paket Wisata dengan Pembayaran Online Menggunakan Payment Gateway pada aplikasi Android (Studi Kasus: CV Ambarawa Raya Travel Agent)," no. 1, pp. 1-20, 2016.

[9] Y. Prasetyo and J. Sutopo, "Implementasi Layanan Payment Gateway Pada Sistem Informasi Transaksi Pembayaran," eprint uty, 2020.

[10] I. O. Suzanti, N. Fitriani, A. Jauhari and A. Khozaimi, "Rest API Implementation on Android Based Monitoring Application," J. Phys. Conf. Ser., vol. 1569, no. 2, 2020. 